\title{
Merger Motives For U.S. Utility Acquirers: Evidence From Performance, Risk Metrics, And Executive Compensation
}

\author{
Sema Dube, (E-mail: semadube@yahoo.com), State University of New York Institute of Technology \\ Laura Francis-Gladney, State University of New York Institute of Technology \\ Rafael Romero, (E-mail: Rafael.Romero@ sunyit.edu), State University of New York Institute of Technology \\ William Langdon, State University of New York Institute of Technology
}

\begin{abstract}
We study post-acquisition performance of US public utilities that acquired other US exchange listed firms during 1996-2002. We find that acquirer shareholders do not gain any abnormal returns from the acquisition over the two years following the acquisition and there are no unexpected gains in the underlying operating performance of the acquirers. We also find that while stock acquirers show a decrease in post-acquisition performance, their CEO salary increases relative to the industry. This suggests that method of payment may be an important factor in discerning the motivation for an acquisition. Lack of clarity regarding effects of a complex process like an acquisition, for shareholders and perhaps the even the management, combined with potential increase in prestige and salary for the management, may be the motivation for $M \& A$ activity in stock mergers. Cash acquirers may be more careful and consequently do not show subsequent underperformance.
\end{abstract}

\section{INTRODUCTION}

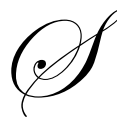

ignificant Merger and Acquisition (M\&A) activity commenced for the utility industry following the Energy Policy Act of 1992. The restructurings are in response to deregulation efforts because of technological advancements such as efficient small-scale plants, and transmission systems that facilitate distribution over wider areas, reducing entry barriers and the need for local monopolies (Becker-Blease et al., 2004). Typical reasons why mergers would benefit consumers and shareholders are similar to those provided for M\&A activity in other industries, such as potential increases in efficiency, economies of scale, diversification in the sources of power generation and geographic diversification leading to correction of regional imbalances.

Results from prior research into whether mergers and acquisitions benefit acquirer shareholders, or the economy as a whole, have been sufficiently contradictory that surveys of the same literature reach different interpretations (Buchholtz, 1991) ${ }^{1}$. For M\&A activity in general, acquirer shareholders lose in $65 \%$ of the cases around the time of the announcement (Sirower and O'Byrne, 1998). Whether this is because of market inefficiency and acquirer shareholders recoup the losses over the long term is unclear due to methodological biases in long-term studies. However research (e.g. Cakici, 2004) based on recent methodological prescriptions of Barber and Lyon, (1997), Lyon et al (1999) and Mitchell and Stafford (2000) tends to support Fama's (1998) contention that the evidence against market inefficiency is weak and evidence of mispricing disappears when methodological biases are removed.

Utility mergers differ from those in unregulated industries in that there is greater regulatory oversight and it takes longer to accomplish the mergers. Additionally, there are restrictions on what benefits can be retained by the company and what must be passed on to the consumers (see for example Berry, 1998; Blecker-Blease et al., 2004).

\footnotetext{
${ }^{1}$ For example Mueller (1980), Halpern (1983), Jensesn and Ruback (1983), Lubatkin (1983), Conn (1985), and Caves (1989). See also Hubbard and Palia (1999) and Agrawal and Jaffe (2000).
} 
However Blecker-Blease et al. (2004) find, in line with merger and acquisitions studies of unregulated industries, that mergers and acquisitions in the utility industry did not create economic value for the acquirer shareholders, or for the economy as a whole.

Our study of the post-acquisition performance of US utilities that acquired other US exchanged listed firms during 1996-2002 also suggests that acquirer shareholders do not gain any abnormal returns from the acquisition over the two years following the acquisition and that stock acquirers showed a decrease in performance. There was no unexpected gain in the underlying operating performance of the company. We also find that the CEO salary increased relative to the industry for stock mergers. This suggests that method of payment may be an important factor in discerning the motivation for an acquisition. Lack of clarity regarding effects of a complex process like an acquisition, for shareholders and perhaps the even the management, combined with potential increase in prestige and salary for the management, may be the motivation for M\&A activity in stock mergers. Cash acquirers may be more careful and consequently do not show subsequent underperformance. However, results from cash mergers should be interpreted with caution due to the small sample size.

The remainder of this paper is organized as follows. Section 2 describes the data and research methodology. Section 3 presents the results of our analyses. Concluding remarks are provided in Section 4.

\section{DATA AND EMPIRICAL METHODS}

We consider completed acquisitions of U.S. firms listed on New York Stock Exchange (NYSE), American Stock Exchange (AMEX) and National Association of Securities Dealers Automated Quotation System (NASDAQ) by exchange listed U.S. public utility firms during 1996-2002. The initial list of firms is obtained from the Mergers and Acquisitions database of Global Securities Information, Inc. (GSI). A search in the database for completed acquisitions by of U.S. target firms by U.S. public utility firms returns 135 deals between 1996 and 2002. Following the methodology of Mitchell and Stafford (2000), if an acquirer firm carries out multiple acquisitions within 3 years of the first acquisition, we ignore the subsequent acquisitions and exclude those deals from our sample to avoid cross sectional correlations. Eliminating multiple acquisitions by the same acquirer and deals involving acquirer firms that do not exist in the Center for Research in Security Prices (CRSP) database leads to a final sample of 76 acquisitions completed by U.S. public utility firms during 1996-2002. We obtain market-related data for firms from the daily CRSP database, and the accounting data from the quarterly Compustat database. Executive compensation data is from the Compustat ExecuComp database, which includes compensation data for approximately 2,600 largest publicly traded firms.

Table 1 presents the sample description. Our full sample has 48 stock mergers, 23 cash mergers and 5 mixed mergers, where payment method includes both stock and cash. For the full sample, 29\% of the acquisitions are realized in the year 2000. All of the cash mergers occurred during 1999-2002, the second half of the sample period, and $52 \%$ of cash mergers are in 2000. Stock mergers are distributed relatively more evenly over the sample period 1996-2002. The highest number of stock mergers occurred in 1997 and 1998, during which period there are no cash mergers in our sample. $73 \%$ of stock mergers and 56\% cash mergers are focus increasing deals where targets and acquirers are in the same two-digit Standard Industrial Classification (SIC) code. Acquirer firms are either electric or gas utilities in both stock mergers and cash mergers with the exception of 3 water utilities in the sample of stock mergers. Both stock and cash mergers have a similar distribution of around two-thirds electric utilities and one-third gas.

\section{Stock Performance}

We investigate the abnormal post-acquisition share performance of utility acquirer firms based on precision weighted cumulative average abnormal returns (CAARs) with Patell $\mathrm{Z}$ tests adjusted for serial dependence (Patell, 1976; Mikkelson and Patch, 1988), and buy-and-hold abnormal returns (BHARs) using skewness corrected t-statistics (Lyon et al., 1999). We also used the generalized sign $Z$ test for CAARs and BHARs, a nonparametric test controlling for the asymmetry of positive and negative abnormal returns during the estimation period (Cowan, 1992). Our pre- 
acquisition period is the two years before the announcement of the acquisition, while the post-acquisition period is the two years after the completion of the acquisition.

Table 1: Sample

The full sample includes 76 mergers including 48 stock mergers, 23 cash mergers and 5 stock and cash mergers. All mergers are completed during 1996-2002 and obtained from Mergers and Acquisitions database of Global Securities Information, Inc. The distribution of mergers over the years, number of same industry and different industry mergers, merger transaction values in 2002 dollars and change in pre- to post-acquisition percentage change in executive compensation are presented. Targets with same 2-digit SIC refer to cases where the target and acquirer firms have the same two-digit Standard Industrial Classification (SIC) codes while Targets with different 2-digit SIC are those acquisitions where the target and acquirer firms do not have the same two-digit Standard Industrial Classification codes. Consumer Price Index used in converting the transaction value to 2002 dollars is obtained from the Bureau of Labor Statistics.

\section{Distribution of Mergers} $1996-2002$

$1996 \quad 3$

$1997+10$

$1998+12$

$1999 \quad 6$

$2000 \quad 22$

2001

2002

Targets with same 2-digit SIC 49

Targets with different 2-digit SIC

Target SIC Unidentified

Acquirer Firms

Electric Utilities

Gas Utilities

Water Utilities

Target Firms

Electric Utilities

Gas Utilities

Water Utilities

Other Industry

Unidentified

Transaction Value (Millions)

Mean

Median

Minimum

Maximum

16
11

45
28
3

22
33
6
5
10

$\$ 1,367$
$\$ 308$
$\$ 3$
$\$ 8,629$

Stock Mergers

$\begin{array}{cc}48 & 23 \\ 3 & 0 \\ 10 & 0 \\ 12 & 0 \\ 4 & 2 \\ 8 & 12 \\ 6 & 2 \\ 5 & 7 \\ 35 & 13 \\ 7 & 7 \\ 6 & 3\end{array}$

29

16

3

$14 \quad 7$

$23-8$

4 2

1 3

$6-3$

Abnormal stock return for a sample firm $i$ on day $t$ is the stock return of the firm $i$ in excess of the benchmark return for that day,

$A_{i t}=R_{i t}-R_{\text {benchmark, }}$

The average abnormal return on day $t$ is estimated as the sample mean for that day, and for a sample of $N$ firms,

$A A R_{t}=\frac{\sum_{i=1}^{N} A_{i t}}{N}$ 
The CAAR is then estimated over a period starting on day $T_{l}$ relative to the event day and ending on day $T_{2}$,

$$
C A A R_{T_{1}, T_{2}}=\frac{1}{N} \sum_{i=1}^{N} \sum_{t=T_{1}}^{T_{2}} A_{i t}
$$

We follow Cowan (2003) to estimate the precision weighted CAARs using the relative weights implied by Patell Z statistics for the null hypothesis of no abnormal returns (Patell, 1976).

Precision weighted $C A A R_{T_{1}, T_{2}}=\frac{1}{N} \sum_{i=1}^{N} \sum_{t=T_{1}}^{T_{2}} w_{i} A_{i t}$

where

$$
w_{i}=\frac{\left(\sum_{t=T_{1}}^{T_{2}} s_{A_{i t}}^{2}\right)^{-\frac{1}{2}}}{\sum_{i=1}^{N}\left(\sum_{t=T_{1}}^{T_{2}} s_{A_{i t}}^{2}\right)^{-\frac{1}{2}}}
$$

and $s^{2}$ is the maximum likelihood variance estimate for $A_{i t}$.

Benchmark returns are obtained using the market model,

$R_{i t}=\alpha_{i}+\beta_{i} R_{m t}+\varepsilon_{i t}$

where $R_{i t}$ is the sample firm $i$ 's stock return on day $t, R_{m t}$ is the rate of return on the market index on day $t$; and $\epsilon_{j t}$ is the corresponding homoscedastic error term with an expected value of zero and uncorrelated with other firms' stock returns and the market return. Parameters $\alpha_{i}$ and $\beta_{i}$ to generate the benchmark return are estimated over the 255 day estimation window ending 46 days before the acquisition announcement date, using ordinary least square estimates.

BHARs are compounded daily returns in excess of benchmark returns estimated using the market model (Equation 6), over a period starting on day $T_{1}$ relative to the event day and ending on day $T_{2}$. For each sample firm, $i$,

$$
B_{H A R}=\prod_{t=T_{1}}^{T_{2}}\left(1+R_{i t}\right)-\prod_{t=T_{1}}^{T_{2}}\left(1+R_{\text {benchmarkt }}\right)
$$

We use two different measures for the market index in estimation of the benchmark returns for both CAARs and BHARs: Dow Jones Utilities Index and CRSP size deciles indices. Size decile indices are created by ranking all CRSP stocks based on their market capitalizations. Each firm in the sample is matched to a size decile index on the event date.

Besides abnormal returns we also examine whether there are any changes in the systematic risk and total equity risk for the sample acquirer firms during the two years after the acquisition, using the three-factor Fama-French (1993) regression following Boehme and Sorescu (2002). We estimate the Fama-French regression for each acquirer firm, using daily returns for 2 years before the acquisition announcement and two years after the acquisition completion.

$$
R_{i t}-R_{f t}=\alpha_{i}+\beta_{i}\left(R_{m t}-R_{f t}\right)+\gamma_{i}\left(S M B_{t}\right)+\delta_{i}\left(H M L_{t}\right)+e_{i t}
$$


where $R_{i t}$ and $R_{f t}$ are the daily returns for each firm and one-month Treasury bill, respectively, $R_{m t}$ is the valueweighted (VW) market return, $S M B_{t}$ is the difference between the VW returns on small firms and big firms, and $H M L_{t}$ is the difference between the VW returns on high book-to-market firms and low book-to-market firms. Crosssectional averages of pre- to post-acquisition changes in the Fama-French factors are reflected in the risk coefficients of $\beta_{i \Delta}, \gamma_{i \Delta}$ and $\delta_{i \Delta}$. Pre- to post-acquisition change in systematic risk is measure by $\beta_{i \Delta}$ while change in equity risk, $\square \Delta K$, is estimated using mean daily Fama-French factors over the sample period (Boehme and Sorescu, 2002).

$\Delta \mathrm{K}=\left(\beta_{\mathrm{i} \Delta} *\right.$ mean $\left.\left[\mathrm{R}_{\mathrm{mt}}-\mathrm{R}_{\mathrm{ft}}\right]\right)+\left(\gamma_{\mathrm{i} \Delta} * \operatorname{mean}\left[\mathrm{SMB}_{\mathrm{t}}\right]\right)+\left(\delta_{\mathrm{i} \Delta} *\right.$ mean $\left.\left[\mathrm{HML}_{\mathrm{t}}\right]\right)$

\section{Operating Performance}

Barber and Lyon (1996) suggest using cash flow based performance measures rather than accounting measures such as return on book value of equity or assets, for studying abnormal operating performance following an event. We use operating margin defined as operating cash flows divided by net sales as our primary measure. Operating cash flows are defined as earnings before interest, taxes, depreciation and amortization. We scale operating cash flows by net sales to facilitate comparisons across firms and time periods (Barber and Lyon, 1996; Healy et al., 1992, 1997). Using operating assets instead of net sales would have been more appropriate (Healy et al. 1997). However, we are unable to measure the true value of operating assets, and using proxies such as book value of debt plus market value of equity may lead to more biases compared to using net sales. We also examine return on capital, book-to-market value of equity and debt-to-equity ratios. Return on capital is net income divided by sum of total equity and debt. Book-toMarket is the ratio of book value of equity to market value of equity, which is the product of stock price per share and number of stocks outstanding. Debt-to-Equity is the ratio of book value of total debt to book value of total equity. Results are presented for the full sample of utility mergers as well as stock and cash mergers. All variables are adjusted for industry and estimated using quarterly Compustat data. Following Barber and Lyon (1996), median values along with Wilcoxon rank sum tests are examined to detect any pre- to post-acquisition change in the industry adjusted variables.

We form industry benchmarks using the S\&P Super Composite 1500 Index, which is a broad market index representing $90 \%$ of the U.S. equities and includes the S\&P 500, the S\&P Mid cap 400 and the S\&P Small cap 600 Indices. Each sample acquirer firm is assigned to a business sector that includes all companies in the S\&P Super Composite 1500 Index with the same SIC code as the sample firm. Industry adjusted variables for each sample firm are the acquirer firm's values in excess of its corresponding business sector mean values.

We estimate the average pre- to post-acquisition change in a variable for each firm as the difference between the industry adjusted median value over the eight-quarter (i.e., two year) post-acquisition period and that over the eight-quarter pre-acquisition period. ${ }^{2}$ We are unable to extend the post-acquisition period beyond two years due to the lack of data as the sample period ends in 2002.

\section{Executive Compensation}

We examine the mean and median changes in CEO (Chief Executive Officer) annual cash compensation and total annual compensation for the full sample and the samples of stock mergers and cash mergers. There are 30 stock mergers and 15 cash mergers which have executive compensation data. The full sample has 47 transactions with available data, two of which are transactions with mixed stock and cash payment. Cash compensation includes total salary and bonus payments. Total compensation includes salary, bonus, other annual, total value of restricted stocks granted, total value of stock options granted (estimated using Black-Scholes), long-term incentive payouts and all other payments made in a year.

We first compute the average compensation during the two year before the announcement and that during the two year after the acquisition completion. One year data is missing for five firms in stock mergers and two firms in

\footnotetext{
${ }^{2}$ We ignore the quarter period that includes the acquisition announcement or completion month to avoid problems due to the difference in timing following Healy et al. (1997), who also compare post-acquisition operating performance to pre-acquisition performance.
} 
cash mergers. For these firms we use one year data instead of the average of two years. For each sample firm, we also estimate mean and median CEO compensation levels for the industry, where we define industry as the ExecuComp universe of utility firms with SIC codes 4900-4949.

We obtain industry adjusted values for each sample firm, by dividing the compensation paid by the firm by the industry median for the corresponding period. Percentage changes from pre- to post-acquisition periods are reported for full sample, stock mergers and cash mergers. We use t-tests for significance of means and Wilcoxon signed rank tests for significance of medians.

\section{RESULTS}

Table 2 presents abnormal stock performance results for utility acquirer firms. Panels A.1 and A.2 show CAAR and BHAR results for full sample. Corresponding results for stock mergers are in Panels B.1 and B.2, and for cash mergers in Panels C.1 and C.2.

Full sample results during the event window, starting one day before the announcement to one day after the completion are almost all insignificant, except that cash mergers show some positive CAAR relative to CRSP size deciles.

Table 2: Abnormal Stock Returns For Utility Mergers During 1996-2002

Abnormal stock performance for utility acquirers is presented. Panel A shows the results for the full sample while Panels B and C present the results for stock mergers and cash mergers, respectively. Section 1 of each panel shows cumulative average abnormal returns (CAARs) which are estimated over a period starting on day $\mathrm{T}_{1}$ relative to the event day and ending on day $\mathrm{T}_{2}$.

$$
\operatorname{CAAR}_{T_{1}, T_{2}}=\frac{1}{N} \sum_{i=1}^{N} \sum_{t=T_{1}}^{T_{2}} A_{i t}
$$

Abnormal return for each sample firm on a day $t$ is the firm's stock return in excess of its benchmark return on the same day. Precision weighted CAAR, a standardized mean CAAR (Cowan, 2003), is reported.

Section 2 of each panel shows the results for buy and hold abnormal returns (BHARs) as compounded daily returns in excess of benchmark returns over the estimation window.

$$
B H A R_{i}=\prod_{t=T_{1}}^{T_{2}}\left(1+R_{i t}\right)-\prod_{t=T_{1}}^{T_{2}}\left(1+R_{\text {benchmarkt }}\right)
$$

The benchmark returns for both panels are obtained using the market model. The market index has 2 different measures: Dow Jones Utilities Index and CRSP Sice Decile Indices. Size decile Indices are created by ranking all CRSP stocks based on their market capitalizations. Each stock in the sample is matched to a size decile index on the event date.

$\mathrm{N}$ is number of events with available data. $\mathrm{Z}$ is the statistics for the Patell $\mathrm{Z}$ test (Patell, 1976), and is adjusted for serial dependence (Mikkelson and Patch, 1988). Skewness-corrected T-test is the normal test adjusted for skewness (Hall, 1992). Generalized sign Z test is a nonparametric test controlling for the asymmetry of positive and negative abnormal returns during the estimation period (Cowan, 1992). The symbols $\$,{ }^{*}, *$, and $* * *$ denote statistical significance at $10 \%, 5 \%, 1 \%$ and $0.1 \%$ levels, respectively. 
Panel A.1 Full Sample: Cumulative Average Abnormal Returns (Caar)

\begin{tabular}{|c|c|c|c|c|c|}
\hline Days & $\mathbf{N}$ & CAAR & Positive: Negative & $\mathbf{Z}$ & Generalized \\
\hline \multicolumn{6}{|c|}{ tion 1. Benchmark: Market Model, Dow Jones Utilities Index } \\
\hline$(-504,-2)$ & 74 & $-0.40 \%$ & $33: 41$ & -0.134 & -0.646 \\
\hline$(-1,+1)$ & 74 & $1.27 \%$ & $36: 38$ & -0.364 & 0.052 \\
\hline$+2,+504)$ & 73 & $-9.00 \%$ & $34: 39$ & $-2.686 * *$ & -0.200 \\
\hline \multicolumn{6}{|c|}{ tion 2. Benchmark: Market Model, CRSP Size Deciles Indices } \\
\hline$(-504,-2)$ & 74 & $4.30 \%$ & $37: 37$ & 1.239 & 0.270 \\
\hline$(-1,+1)$ & 74 & $7.18 \%$ & $41: 33$ & 0.947 & 1.200 \\
\hline$+2,+504)$ & 73 & $-4.74 \%$ & $31: 42$ & -1.264 & -0.993 \\
\hline
\end{tabular}

\begin{tabular}{|c|c|c|c|c|c|}
\hline \multicolumn{5}{|c|}{ Panel A.2 Full Sample: Mean Buy And Hold Abnormal Returns (BHAR) } & \multirow[b]{2}{*}{ Generalized S } \\
\hline Days & $\mathbf{N}$ & BHAR & Positive: Negative & Skewness-corrected T-stat. & \\
\hline \multicolumn{6}{|c|}{ ction 1. Benchmark: Market Model, Dow Jones Utilities Index } \\
\hline$(-504,-2)$ & 74 & $-71.97 \%$ & $30: 44$ & $-2.129 *$ & -1.344 \\
\hline$(-1,+1)$ & 74 & $-1.40 \%$ & $35: 39$ & -0.453 & -0.181 \\
\hline$(+2,+504)$ & 73 & $-93.47 \%$ & $32: 41$ & $-3.203 * *$ & -0.669 \\
\hline \multicolumn{6}{|c|}{ ction 2. Benchmark: Market Model, CRSP Size Deciles Indices } \\
\hline$(-504,-2)$ & 74 & $38.20 \%$ & $35: 39$ & $-2.147 *$ & -0.196 \\
\hline$(-1,+1)$ & 74 & $0.42 \%$ & $38: 36$ & 0.142 & 0.502 \\
\hline$(+2,+504)$ & 73 & $-57.13 \%$ & $29: 44$ & $-2.842 * *$ & -1.461 \\
\hline
\end{tabular}

\begin{tabular}{lll} 
& \multicolumn{3}{l}{ Panel B.1 Stock Mergers: Cumulative Average Abnormal Returns (Caar) } \\
Days & CAAR & Positive: Negative
\end{tabular} Section 1. Benchmark: Market Model, Dow Jones Utilities Index

$\begin{array}{cccccc}(-504,-2) & 48 & 0.89 \% & 26: 22 & 0.229 & 0.923 \\ (-1,+1) & 48 & -1.36 \% & 22: 26 & -0.818 & -0.299 \\ (+2,+504) & 48 & -9.67 \% & 17: 31 & -2.667 * * & -1.744 \$ \\ \text { tion 2. Benchmark: } & \text { Market Model, CRSP Size Deciles Indices } & & & \\ (-504,-2) & 48 & 1.70 \% & 25: 23 & 0.396 & 0.586 \\ (-1,+1) & 48 & 3.28 \% & 24: 24 & -0.075 & 0.281 \\ (+2,+504) & 48 & -5.18 \% & 20: 28 & -1.262 & -0.875\end{array}$

\begin{tabular}{|c|c|c|c|c|c|}
\hline \multicolumn{6}{|c|}{ Panel B.2 Stock Mergers: Mean Buy And Hold Abnormal Returns (BHAR) } \\
\hline Days & $\mathbf{N}$ & BHAR & Positive: Negative & Skewness-corrected T-stat. & Generalized $\mathrm{Si}$ \\
\hline \multicolumn{6}{|c|}{ ection 1. Benchmark: Market Model, Dow Jones Utilities Index } \\
\hline$(-504,-2)$ & 48 & $-86.19 \%$ & $23: 25$ & -1.603 & 0.056 \\
\hline$(-1,+1)$ & 48 & $-3.08 \%$ & $22: 26$ & -0.798 & -0.299 \\
\hline$(+2,+504)$ & 48 & $-52.32 \%$ & $16: 32$ & $-2.963 * *$ & $-2.033^{*}$ \\
\hline \multicolumn{6}{|c|}{ ection 2. Benchmark: Market Model, CRSP Size Deciles Indices } \\
\hline$(-504,-2)$ & 48 & $-46.16 \%$ & $21: 27$ & $-1.867 \$$ & -0.570 \\
\hline$(-1,+1)$ & 48 & $-2.52 \%$ & $22: 26$ & -0.700 & -0.297 \\
\hline$(+2,+504)$ & 48 & $-38.18 \%$ & $19: 29$ & $-2.790 * *$ & -1.164 \\
\hline
\end{tabular}

\begin{tabular}{|c|c|c|c|c|c|}
\hline \multicolumn{6}{|c|}{ Panel C.1 Cash Mergers: Cumulative Average Abnormal Returns (Caar) } \\
\hline Days & $\mathbf{N}$ & CAAR & Positive: Negative & $\mathbf{Z}$ & Generalized S \\
\hline \multicolumn{6}{|c|}{ tion 1. Benchmark: Market Model, Dow Jones Utilities Index } \\
\hline$(-504,-2)$ & 22 & $-0.42 \%$ & $11: 11$ & -0.540 & 0.480 \\
\hline$(-1,+1)$ & 22 & $26.26 \%$ & $12: 10$ & 0.754 & 0.475 \\
\hline$(+2,+504)$ & 22 & $3.75 \%$ & $13: 9$ & 0.416 & 1.009 \\
\hline \multicolumn{6}{|c|}{ tion 2. Benchmark: Market Model, CRSP Size Deciles Indices } \\
\hline$(-504,-2)$ & 22 & $11.43 \%$ & $13: 9$ & 1.606 & 0.881 \\
\hline$(-1,+1)$ & 22 & $32.73 \%$ & $14: 8$ & $2.102 *$ & 1.308 \\
\hline$(+2,+504)$ & 22 & $17.26 \%$ & $13: 9$ & $1.966^{*}$ & 0.929 \\
\hline
\end{tabular}




\begin{tabular}{|c|c|c|c|c|c|}
\hline \multicolumn{6}{|c|}{ Panel C.2 Cash Mergers: Mean Buy And Hold Abnormal Returns (BHAR) } \\
\hline Days & $\mathbf{N}$ & BHAR & Positive: Negative & Skewness-corrected T-stat. & Generalized Sign $\mathbf{Z}$ \\
\hline \multicolumn{6}{|c|}{ Section 1. Benchmark: Market Model, Dow Jones Utilities Index } \\
\hline$(-504,-2)$ & 22 & $-3.94 \%$ & $8: 14$ & -0.459 & -1.232 \\
\hline$(-1,+1)$ & 22 & $2.37 \%$ & $11: 11$ & 0.426 & 0.048 \\
\hline$(+2,+504)$ & 22 & $-95.19 \%$ & $12: 10$ & -1.391 & 0.582 \\
\hline \multicolumn{6}{|c|}{ Section 2. Benchmark: Market Model, CRSP Size Deciles Indices } \\
\hline$(-504,-2)$ & 22 & $8.25 \%$ & $12: 10$ & 0.933 & 0.455 \\
\hline$(-1,+1)$ & 22 & $6.18 \%$ & $14: 8$ & 1.115 & 1.308 \\
\hline$(+2,+504)$ & 22 & $-0.24 \%$ & $12: 10$ & -0.013 & 0.503 \\
\hline
\end{tabular}

For the two years following the acquisition, the full sample shows significantly negative CAAR relative to its industry peers proxied by the Dow Jones Utility Index (-9\% significant at the $1 \%$ level), while relative to firms in the same CRSP size deciles, CAAR is negative but statistically insignificant. Full sample BHAR is negative and statistically significant relative to both Dow Jones (-93.47\%, significant at 1\%) and CRSP size deciles (-57.13\%, significant at $1 \%$ ). These results are primarily due to stock mergers, which show similar results, at the same level of significance. In contrast cash mergers show positive post-acquisition CAARs with the value relative to CRSP size deciles being significant (17.26\% significant at 5\%), while BHARs, while negative, are not statistically significant. Although our sample of cash mergers is smaller, overall stock mergers seem to show a greater tendency towards post-acquisition underperformance.

The pre-acquisition values based on market parameters computed over the year prior to the announcement are shown for completeness. Overall these results are either insignificant or only marginally so, for both cash and stock mergers, implying that these firms did not show unusual pre-event performance. We also calculate abnormal performance during the two-year pre-acquisition period based on market model parameters estimated three years before the acquisition. Results (not reported) were similar for cash and stock, and the significance seen for full sample BHAR also disappears in this case, confirming lack of unusual pre-event performance.

Table 3 indicates that cash mergers have a marginally significant increase in their systematic risk during the two year period following acquisitions. There are no other post-acquisition changes in Fama-French risk factors or equity risk for cash mergers. Similarly, utility firms involved in stock mergers did not have any changes in their systematic risk or equity risk during the two year pre-acquisition period.

\section{Table 3: Post-Acquisition Changes In Systematic Risk And Equity Risk}

The Fama-French regression (1993) is estimated for each firm, for days $(m-n, m+n)$, where $m$ is the acquisition announcement date for the pre-acquisition period, and acquisition completion date for the post-acquisition period, and $\mathrm{n}$ equals 504 , which is the number of trading days in 2 years:

$R_{i t}-R_{f t}=\alpha_{i}+\beta_{i}\left(R_{m t}-R_{f t}\right)+\gamma_{i}\left(S M B_{t}\right)+\delta_{i}\left(H M L_{t}\right)+e_{i t}$

$R_{i t}$ and $R_{f t}$ are the daily returns for each firm and one-month Treasury bill, respectively, $R_{m t}$ is the valueweighted $(\mathrm{VW})$ market return, $\mathrm{SMB}_{\mathrm{t}}$ is the difference between the VW returns on small firms and big firms, and $\mathrm{HML}_{\mathrm{t}}$ is the difference between the VW returns on high book-to-market firms and low book-to-market firms. The period between acquisition announcement and completion dates is excluded following Boehme and Sorescu (2002). Cross-sectional averages of pre- to post-acquisition changes in the Fama-French factors are reflected in the risk coefficients of $\beta_{\mathrm{i} \Delta}, \gamma_{\mathrm{i} \Delta}$ and $\delta_{\mathrm{i} \Delta}$. The post-acquisition change in equity risk is estimated using mean daily Fama-French factors over the sample period (Boehme and Sorescu 2002).

$\Delta \mathrm{K}=\left(\beta_{\mathrm{i} \Delta} * \operatorname{mean}\left[\mathrm{R}_{\mathrm{mt}}-\mathrm{R}_{\mathrm{ft}}\right]\right)+\left(\gamma_{\mathrm{i} \Delta} * \operatorname{mean}\left[\mathrm{SMB}_{\mathrm{t}}\right]\right)+\left(\delta_{\mathrm{i} \Delta} *\right.$ mean $\left.\left[\mathrm{HML}_{\mathrm{t}}\right]\right)$. 
$\mathrm{N}$ is the number of events with available data. P-values associated with t-tests are presented.

\begin{tabular}{|c|c|c|c|}
\hline & $\begin{array}{c}\text { Full Sample } \\
(\mathbf{N}=73)\end{array}$ & $\begin{array}{l}\text { Stock Mergers } \\
\quad(N=48)\end{array}$ & $\begin{array}{c}\text { Cash Mergers } \\
\quad(\mathrm{N}=\mathbf{2 2})\end{array}$ \\
\hline \multicolumn{4}{|c|}{ Pre-event values } \\
\hline$\alpha_{\mathrm{i}}$ & 0.0003 & 0.0002 & 0.0003 \\
\hline p-value & 0.0575 & 0.1241 & 0.9218 \\
\hline$\beta_{\mathrm{i}}$ & 0.7223 & 0.7360 & 0.7136 \\
\hline p-value & 0.0000 & 0.0000 & 0.0000 \\
\hline$\gamma_{\mathrm{i}}$ & 0.1153 & 0.1479 & 0.1482 \\
\hline p-value & 0.0195 & 0.0103 & 0.0932 \\
\hline$\delta_{\mathrm{i}}$ & 0.7339 & 0.7148 & 0.8609 \\
\hline p-value & 0.0000 & 0.0000 & 0.0000 \\
\hline \multicolumn{4}{|c|}{ Post-event change } \\
\hline$\alpha_{\mathrm{i} \Delta}$ & -0.0004 & -0.0002 & -0.0004 \\
\hline $\mathrm{p}$-value & 0.0752 & 0.1519 & 0.5046 \\
\hline$\beta_{\mathrm{i} \Delta}$ & 0.0766 & -0.0131 & 0.1941 \\
\hline $\mathrm{p}$-value & 0.0988 & 0.6874 & 0.0713 \\
\hline$\gamma_{\mathrm{i} \Delta}$ & 0.0053 & -0.0206 & 0.0264 \\
\hline p-value & 0.9053 & 0.5166 & 0.8311 \\
\hline$\delta_{\mathrm{i} \Delta}$ & 0.1753 & 0.0502 & 0.2305 \\
\hline $\mathrm{p}$-value & 0.0090 & 0.1726 & 0.2229 \\
\hline \multicolumn{4}{|c|}{ Fama French Factors } \\
\hline$\left[\mathrm{R}_{\mathrm{mt}}-\mathrm{R}_{\mathrm{ft}}\right]$ & 0.0001 & 0.0001 & -0.0003 \\
\hline p-value & 0.6345 & 0.6345 & 0.4987 \\
\hline$\left[\mathrm{SMB}_{\mathrm{t}}\right]$ & -0.0000 & -0.0000 & 0.0003 \\
\hline p-value & 0.9432 & 0.9432 & 0.2207 \\
\hline$\left[\mathrm{HML}_{\mathrm{t}}\right]$ & 0.0002 & 0.0002 & 0.0003 \\
\hline p-value & 0.2670 & 0.2670 & 0.2494 \\
\hline \multicolumn{4}{|c|}{ Equity risk change } \\
\hline$\Delta \mathrm{K}$ & 0.0000 & 0.0000 & 0.0000 \\
\hline $\mathrm{p}$-value & 0.1285 & 0.2773 & 0.7100 \\
\hline
\end{tabular}

Table 4 presents the pre- to post-acquisition median changes in operating margin, return on capital, book-tomarket and debt-to-equity ratios.

Table 4: Pre- To Post-Acquisition Changes In Industry Adjusted Variables: Operating Margin, Return On Capital, Book-To-Market And Debt-To-Equity

Operating margin is defined as earnings before interest, taxes, depreciation and amortization divided by net sales revenue. Return on Capital is net income divided by sum of total equity and debt. Book-to-Market is the ratio of book value of equity to market value of equity, which is the product of stock price per share and number of stocks outstanding. Debt-to-Equity is the ratio of book value of total debt to book value of total equity. Results are presented for full sample of utility mergers as well as stock and cash mergers.

Pre shows the median value during the 8 quarters prior to the acquisition announcement. Post shows the median value during the 8 quarters after the acquisition completion. Change in value for each firm from pre- to postacquisition is estimated as industry adjusted mean during the two-year post-acquisition period in excess of that during the two year pre-acquisition period. We assign each sample firm to a business sector that includes all companies in the S\&P Super Composite 1500 Index with the same SIC code as the sample firm. Industry adjusted values for each sample 
firm are the firm values in excess of its business sector averages. The S\&P Super Composite 1500 Index is a broad market index representing 90\% of the U.S. equities and includes S\&P 500, S\&P Mid Cap 400 and the S\&P Small Cap 600 indices. All operating variables are adjusted for industry and estimated using quarterly Compustat data. Median values are presented. P-values in brackets are associated with Wilcoxon Signed Ranks tests for Pre and Post values and Wilcoxon rank sum test for Change. The number of events with available data for the full sample, stock mergers and cash mergers are 48,34 and 17 , respectively.

\begin{tabular}{|c|c|c|c|c|c|c|c|c|c|}
\hline \multirow[b]{3}{*}{ Operating Margin (\%) } & \multicolumn{3}{|c|}{ Full Sample } & \multicolumn{3}{|c|}{ Stock Mergers } & \multicolumn{3}{|c|}{ Cash Mergers } \\
\hline & Pre & Post & Change & Pre & Post & Change & Pre & Post & Change \\
\hline & & & & & & & & & \\
\hline Sample & 27.60 & 20.90 & & 28.60 & 22.00 & & 22.16 & 19.26 & \\
\hline Industry & 28.52 & 24.34 & & 30.19 & 24.40 & & 22.39 & 22.75 & \\
\hline Industry adjusted & 1.21 & -1.67 & -0.34 & 1.10 & -1.92 & -1.71 & 1.21 & -0.80 & 2.13 \\
\hline $\begin{array}{l}\text { [p-value] } \\
\text { Return on Canital (\%) }\end{array}$ & {$[0.585]$} & [0.199] & {$[0.216]$} & [0.914] & [0.184] & {$[0.318]$} & {$[0.579]$} & {$[0.562]$} & {$[0.476]$} \\
\hline Return on Capital (\%) & & & & & & & & & \\
\hline Sample & 5.80 & 4.71 & & 5.89 & 4.74 & & 5.38 & 4.35 & \\
\hline Industry & 5.08 & 4.49 & & 5.11 & 4.82 & & 4.95 & 4.28 & \\
\hline $\begin{array}{c}\text { Industry adjusted } \\
{[p \text {-value }]}\end{array}$ & $\begin{array}{c}0.78 \\
{[0.037]}\end{array}$ & $\begin{array}{c}0.39 \\
{[0.242]}\end{array}$ & $\begin{array}{l}-0.50 \\
{[0.726]}\end{array}$ & $\begin{array}{c}0.73 \\
{[0.2011}\end{array}$ & $\begin{array}{c}0.40 \\
{[0.476]}\end{array}$ & $\begin{array}{l}-0.335 \\
{[0.855]}\end{array}$ & $\begin{array}{c}0.79 \\
{[0.145]}\end{array}$ & $\begin{array}{c}0.66 \\
0.7471\end{array}$ & $\begin{array}{l}-0.089 \\
-0.581\end{array}$ \\
\hline Book-to-Market & & & & & & & & & \\
\hline Sample & 0.56 & 0.52 & & 0.58 & 0.54 & & 0.53 & 0.54 & \\
\hline Industry & 0.63 & 0.61 & & 0.62 & 0.62 & & 0.63 & 0.60 & \\
\hline Industry adjusted & -0.06 & -0.06 & -0.003 & -0.04 & -0.06 & 0.000 & -0.08 & -0.06 & -0.01 \\
\hline [p-value] & {$[0.022]$} & {$[0.031]$} & {$[0.785]$} & {$[0.195]$} & {$[0.060]$} & {$[0.461]$} & {$[0.120]$} & {$[0.934]$} & {$[0.552]$} \\
\hline Debt-to-Equity (\%) & & & & & & & & & \\
\hline Sample & 108.90 & 142.27 & & 103.02 & 142.39 & & 113.29 & 143.94 & \\
\hline Industry & 140.47 & 163.03 & & 119.78 & 153.86 & & 155.96 & 185.16 & \\
\hline $\begin{array}{c}\text { Industry adjusted } \\
{[p \text {-value] }}\end{array}$ & $\begin{array}{l}-24.26 \\
{[0.001]}\end{array}$ & $\begin{array}{c}-13.92 \\
{[0.035]}\end{array}$ & $\begin{array}{c}10.71 \\
{[0.265]}\end{array}$ & $\begin{array}{l}-18.07 \\
{[0.006]}\end{array}$ & $\begin{array}{c}-7.15 \\
{[0.201]}\end{array}$ & $\begin{array}{l}14.833 \\
{[0.243]}\end{array}$ & $\begin{array}{l}-44.00 \\
{[0.080]}\end{array}$ & $\begin{array}{l}-18.75 \\
{[0.145]}\end{array}$ & $\begin{array}{c}29.48 \\
{[0.597]}\end{array}$ \\
\hline
\end{tabular}

Analyses of operating margin and return on capital show that utility acquirers experienced no significant preto post-acquisition changes in industry adjusted operating performance in either stock mergers or cash mergers. For both stock mergers and cash mergers, the book-to-market value of equity for acquirer firms is less than one and below the industry average, which is around 0.62. Cash acquirers have a book-to-market value of 0.53 and 0.54 during the two year pre-acquisition and post-acquisition periods, respectively. On the other hand, stock acquirers' pre-acquisition period book-to-market value, 0.58 , decrease to 0.54 during the post-acquisition period, which is significantly lower than its industry level during the same period. Stock mergers' debt-to-equity is significantly lower by 18.07 percent than its industry during the pre-merger period. During the post-merger period this difference decreases and becomes statistically not significant. For the sample of cash mergers, even though the acquirer firms have debt-to-equity levels below their industry, the difference is not statistically significant.

Table 5 illustrates the pre- and post-acquisition levels of CEO annual cash compensation and total compensation as well as post-acquisition percentage change in compensation for full sample, stock mergers and cash mergers. Industry and industry adjusted sample means and medians are also reported. 


\section{Table 5: Post-Acquisition Change In CEO (Chief Executive Officer) Compensation}

Cash compensation is total salary and bonus payments while total compensation is comprised of salary, bonus, other annual, total value of restricted stocks granted, total value of stock options granted (estimated using Black Scholes), long-term incentive payouts and all other total payments made in a year. Pre (post)-acquisition compensation is the average of two years before (after) merger announcement (completion). Data is from Compustat ExecuComp which includes compensation data for approximately 2,600 largest publicly traded firms. Industry is the ExecuComp universe of utility firms with SIC codes 4900-49. Industry adjusted sample is sample firm compensation divided by the industry median compensation in the corresponding period. Pre to Post Change refers to the change in values from pre- to post-acquisition period. Panels A, B and C present the results for full sample, stock mergers and cash mergers, respectively. $\$,{ }^{*}, * *, \& * * *$ are significance at $10 \%, 5 \%, 1 \%$ and $0.1 \%$, respectively. $\mathrm{N}$ is the number of observations.

For stock mergers, the post-acquisition mean cash based CEO compensation increases by approximately $60.41 \%$ compared to pre-acquisition period. Industry adjusted cash compensation for stock mergers also shows an increase of $24.52 \%$ post-acquisition. Total compensation for stock mergers including stock-based components shows a much higher post-acquisition increase for both raw sample and industry adjusted values, $175.55 \%$ and $81.12 \%$, respectively. Post-acquisition changes in both cash and total compensation are statistically significant at $0.1 \%$ for stock mergers. All median values are below mean values, but similar in comparison to those of means. For cash mergers, there is an increase of 36.22 percent in the post-acquisition cash compensation with a marginal significance. However, relative to industry we do not see a significant post-acquisition increase in CEO cash compensation. There is no significant change from pre- to post-acquisition period in total CEO compensation of either of raw sample or industry adjusted sample for cash mergers. We have only 15 firms with available compensation data which does not allow us to draw reliable inferences about the post-acquisition CEO compensation changes for the cash mergers.

Cash Compensation

Sample

Industry

Industry Adjusted Sample

Total Compensation

Sample

Industry

Industry Adjusted Sample

Cash Compensation

Sample

Industry

Industry Adjusted Sample

Total Compensation

Sample
Pre-Acquisition

Mean / Median

Panel A. Full Sample ( $N=47)$

$\$ 914,015$
836,700
699,454
663,390
1.2986
1.3298

$1,945,684$
$1,323,682$
$1,341,828$
$1,218,527$
1.4166
1.1245

Panel B. Stock Mergers $(\mathbf{N}=\mathbf{3 0})$
Post-Acquisition

Mean / Median
Pre to Post Change

Mean / Median
$0.5018 * * *$
$0.4365 * * *$
$0.2421 * * *$
$0.2424 * * *$
$0.2074 * *$
$0.1246 * *$

$1.1502 * * *$
$0.6303 * * *$
$0.4230^{* * *}$
$0.4066 * * *$
$0.5224 * *$
$0.4581 * * *$

1.4594

1.4322

$3,283,457$

$2,452,229$

$1,777,927$

$1,713,975$

1.8566

1.4045
$1,172,496$

$1,115,732$

838,711

843,078

1.4051

1.3529

$3,479,627$

$2,577,237$
0.6041 *** $0.4849 * * *$ $0.2905 * * *$ $0.2930 * * *$ $0.2452 * *$ $01963 * *$

1.7555 *** $1.8079 * * *$
$1,262,341$

$1,103,644$ 


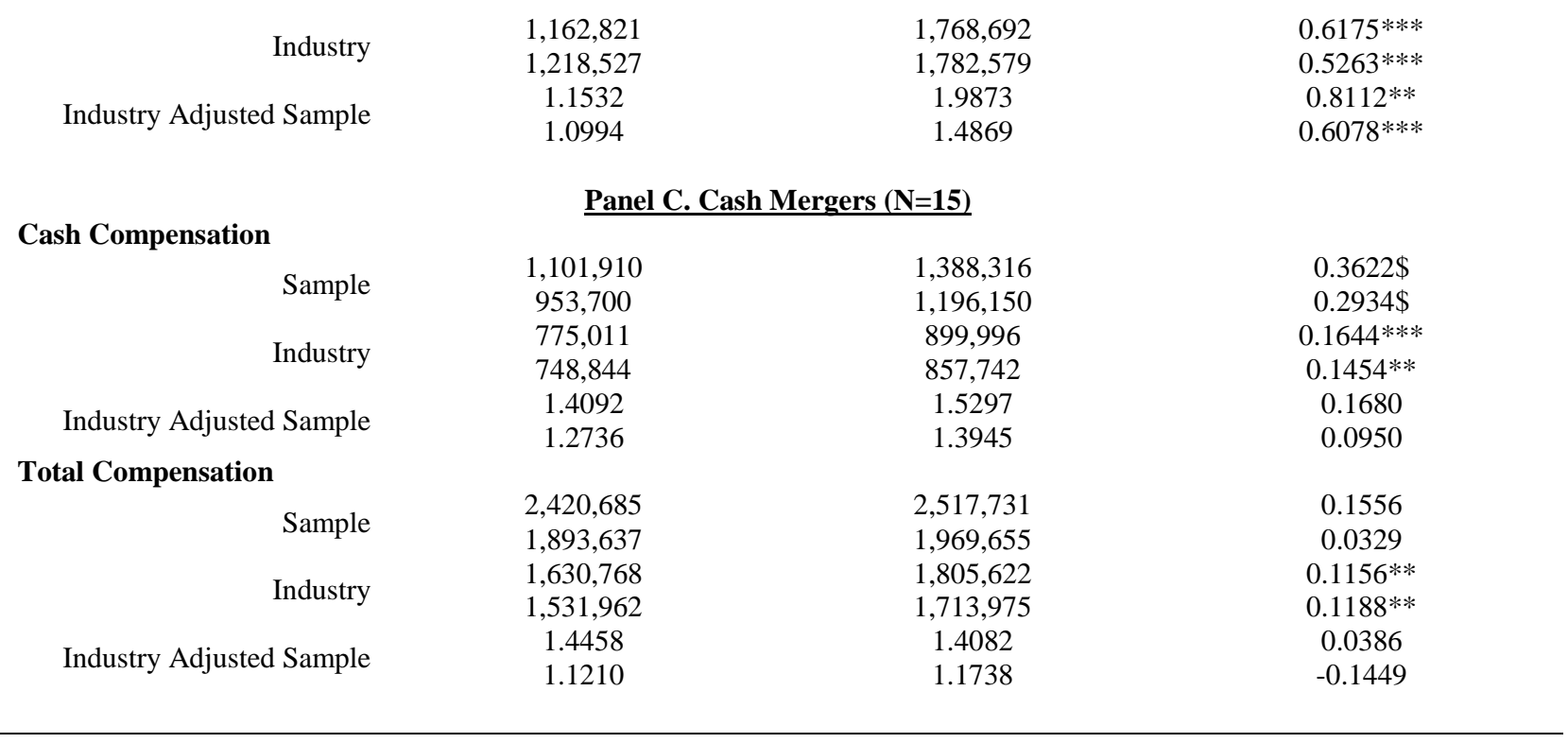

\section{CONCLUDING REMARKS}

Our analyses of U.S. public utility mergers over 1996-2002 for post-acquisition changes in stock and operating performance, and risk metrics including systematic risk and equity risk for the firm show that similar to the results of Becker-Blease et al. (2004) for utilities and in line with studies on mergers and acquisitions in unregulated industries (e.g. Cakici, 2004) we find no evidence that utility mergers led to any economic benefit for acquirer shareholders.

In line with the method of payment hypothesis (see for example Franks et al. 1991; Loughran and Vijh, 1997; Rau and Vermaelen, 1998; Hou et al, 2000) that predicts post-acquisition underperformance for stock acquirers, stock mergers in our sample significantly underperformed their benchmarks during the two years following the acquisition. BHAR and CAAR results show similar trends. Our sample of cash mergers does not show a tendency towards post-acquisition underperformance. We find that companies involved in cash mergers showed a marginal increase in systematic risk. We do not observe any abnormal performance in terms of the underlying operating returns. All samples, and the industry as a whole, have book to market ratios less than 1.

Stock acquisitions were also accompanied by significant increases in CEO compensation. We have compensation data only for 15 cash mergers, and so the results are not statistically reliable. However, for these firms we did not see similar increases as for stock acquirers.

For stock mergers our results suggest that the potential for increased prestige and compensation, in association with the lack of shareholder and even management clarity regarding the effects of a complex transaction such as a merger, may be the prime driver for merger activities that could cause subsequent underperformance. For cash mergers we do not find underperformance or significant increases in CEO compensation, but our sample size is smaller and there is more clustering in time, towards the latter half of the sample period. There is, however, no evidence that shareholders benefited from cash mergers either.

\section{REFERENCES}

1. Agrawal, A. and Jaffe, J. (2000), The Post-Merger Performance Puzzle, Printed in Advances in Mergers and Acquisitions, New York: JAI Series (1) Elsevier Science, pp. 7-41. 
2. Barber, B.M. and Lyon, J.D. (1996), Detecting Abnormal Operating Performance: The Empirical Power and Specification of Test Statistics, Journal of Financial Economics, Vol 41.

3. Barber, B.M. and Lyon, J.D. (1997), Detecting Long-Run Abnormal Stock Returns: The Empirical Power and Specification of Test Statistics, Journal of Financial Economics, Vol 43.

4. $\quad$ Becker-Blease, J.R., Goldberg, L.G., and Kaen, F.R. (2004), Post Deregulation Restructuring of the Electric Power Industry: Value Creation or Value Destruction? Working Paper, University of New Hampshire.

5. Berry, S.K. (1998), Utility Mergers and the Cost of Capital, Journal of Financial and Strategic Decisions, Vol 11 No 1.

6. Boehme, R.D. and Sorescu, S.M. (2002), The Long-Run Performance following Dividend Initiations and Resumptions: Underreaction or Product of Change, Journal of Finance, Vol 57.

7. Buchholtz, Ann K. (1991), The Effects of Takeover Threat on Corporate performance: An Analysis of the Implications of the Efficiency and Myopia Perspectives, Ph.D. Dissertation, New York University, New York.

8. Cakici, S. (2004), Effects of Hostility on the Long-Term Post-Acquisition Performance of Acquirers, Ph.D. Dissertation, The George Washington University, Washington, D.C.

9. Caves, R.E. (1989), Mergers, Takeovers, and Economic Efficiency: Foresight vs. Hindsight, International Journal of Industrial Organization, Vol 7, pp. 151-174.

10. Conn, R. (1985), A Reexamination of Merger Studies that Use the Capital Asset Pricing Model Methodology, Cambridge Journal of Economics, Vol 9, pp.43-56.

11. Cowan, A.R. (1992), Nonparametric Event Study Tests, Review of Quantitative Finance and Accounting, Vol 2 No 4, pp.343-358.

12. Cowan, A.R. (2003), Eventus 7.6 User's Guide, Cowan Research LC, Ames, Iowa.

13. Fama, E.F. (1998), Market Efficiency, Long Term Returns and Behavioral Finance, Journal of Financial Economics, Vol 49, pp.283-306.

14. Fama, E.F. and French, K. (1993), Common Risk Factors in Returns on Stocks and Bonds, Journal of Financial Economics, Vol 33, pp.3-56.

15. Franks, J., Harris, R., and Titman, S. (1991), The Post-Merger Share-Price Performance of Acquiring Firms, Journal of Financial Economics, Vol 29, pp. 81-96.

16. Hall, P. (1992), On the Removal of Skewness by Transformation, Journal of the Royal Statistical Society, Series B (Methodological), Vol 54 No 1, pp.221-228.

17. Halpern, P.J. (1983), Corporate Acquisitions: A Theory of Special Cases, Journal of Finance, Vol 38, pp. 297-317.

18. Healy, P.M., Palepu, K.G., and Ruback, R.S. (1992), Does Corporate Performance Improve after Mergers?, Journal of Financial Economics, Vol 31, pp.135-175.

19. Healy, P.M., Palepu, K.G., and Ruback, R.S. (1997), Which Takeovers are Profitable? Strategic or Financial?, Sloan Management Review (Summer).

20. Hou, K., Robinson, D.T., and Olsson, P. (2000), Do Takeovers Increase Stockholder Value? Working Paper, University Of Chicago.

21. Hubbard, R.G. and Palia, D. (1999), A Reexamination of the Conglomerate Merger Wave in the 1960s: An Internal Capital Markets View, Journal of Finance Vol 54 No 3.

22. Jensen, M.C. and Ruback, R.S. (1983), The Market for Corporate Control: The Scientific Evidence, Journal of Financial Economics, Vol 11, pp.5-50.

23. Loughran, T. and Vijh, A. (1997), Do Long-Term Shareholders Benefit from Corporate Acquisitions? Journal of Finance, Vol 52 No 5.

24. Lubatkin, M. (1983), Mergers and the Performance of the Acquiring Firm, Academy of Management Review, Vol 8 No 2, pp. 218-225.

25. Lyon, J.D., Barber, B.M., and Tsai, C.L. (1999), Improved Methods for Tests of Long-Run Abnormal Stock Returns, Journal of Finance, Vol 54 No 1.

26. Mikkelson, W.H. and Patch, M.M. (1988), Withdrawn Security Offerings, Journal of Financial and Quantitative Analysis, Vol 23 No 2, pp.119-134; "Errata" Vol 23 No 4, pp.487.

27. Mitchell, M.L. and Stafford, E. (2000), Managerial Decisions and Long-Term Stock Price Performance, Journal of Business, Vol 73 No 3. 
28. Mueller, D.C. (1980), The Determinants and Effects of Mergers: An International Comparison, Cambridge, England: Oelgeschlager, Gunn, and Hain.

29. Patell, J.M. (1976), Corporate Forecasts of Earnings Per Share and Stock Price Behavior: Empirical Tests, Journal of Accounting Research, Vol 14 No 2, pp.246-274.

30. Rau, P.R. and Vermaelen, T. (1998), Glamour, Value and the Post-Acquisition Performance of Acquiring Firms, Journal of Financial Economics, Vol 49, pp. 223-253.

31. Sirower, M.L. and O'Byrne, S. (1998), The Measurement of Post-Acquisition Performance: Toward a ValueBased Benchmarking Methodology, Journal of Applied Corporate Finance, Vol 11 No 2.

\section{NOTES}

